\title{
RENAL SURVIVAL AND VALIDATION OF NOVEL INTERNATIONAL IMMUNOGLOBULIN A NEPHROPATHY PREDICTION TOOL IN LATVIAN POPULATION: PRELIMINARY DATA
}

\author{
Anna Jana Saulīte ${ }^{1,2, \#}$, Anna Popova ${ }^{1,2,3}$, Renārs Erts ${ }^{3}$, Kārlis Rācenis ${ }^{1,2}$, \\ Linda Kučāne ${ }^{4}$, Aivars Pētersons ${ }^{1,2}$, Arvydas Laurinavičius ${ }^{5}$, Harijs Čerṇevskis ${ }^{1,2}$, \\ and Viktorija Kuzema ${ }^{1,2}$

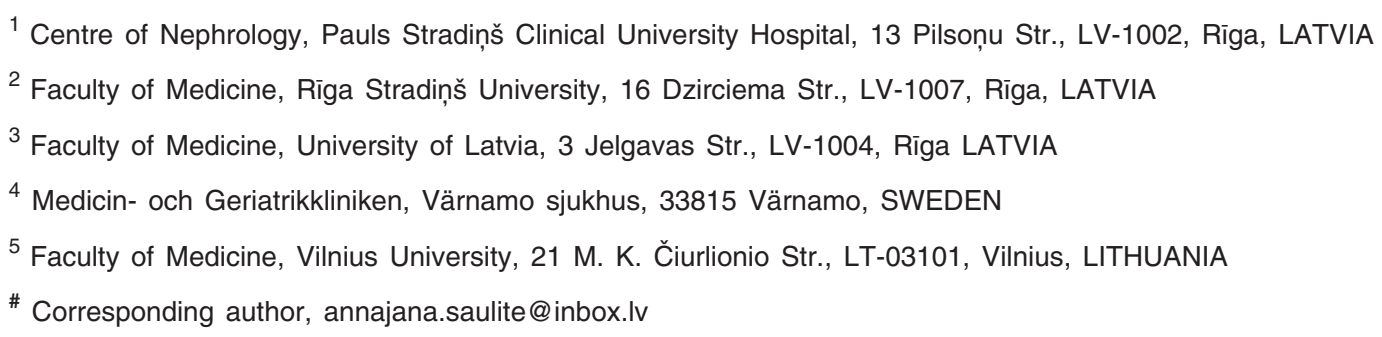

Communicated by Ingrïda Rumba-Rozenfelde

\begin{abstract}
The aim of the study was to determine kidney survival and validate the novel international immunoglobulin A nephropathy (IgAN) prediction tool (PT) in the Latvian population. Adults with morphologically confirmed IgAN were included. Kidney survival was analysed with the Kaplan-Meier method. PT-assigned risk was compared with calculated risk by the Cox regression model. The Kaplan-Meier analysis included 95 patients. The five-year kidney survival Q3 was 24 months. Women had longer median kidney-survival time (> 60 months) than men (58 months). Median kidney survival in participants with MEST TO was longer than 60 months; T1 and T2 were 40 and 18 months, respectively. Median kidney survival in participants with diastolic blood pressure $(D B P)<99 \mathrm{mmHg}$ was longer than 60 months, whereas in patients with DBP 100-109 and 110 $\mathrm{mmHg}$, it was 40 and 24 months, respectively. Cox regression analysis included 68 patients. $A$ moderate degree of correlation was found between predicted and observed five-year risk ( $\mathrm{p}=$ 0.001). Gender, tubular atrophy/interstitial fibrosis, DBP are significant factors affecting kidney survival. Since there was statistically significant correlation and reliability between $P T$ and follow-up analysis data, we conclude that PT could be applied for use in the Latvian population.

Key words: immunoglobulin A nephropathy, novel IgAN prediction tool, kidney survival risk factors, end-stage kidney disease.
\end{abstract}

\section{INTRODUCTION}

Immunoglobulin A nephropathy (IgAN), also known as Berger's disease, is the most common global type of glomerulonephritis; however, the geographical distribution of the disease varies (Rodrigues et al., 2017; Schena and Nistor, 2018). The disease can manifest at any age, but it is more common in young adults, especially in the second and third decade of life (Cheung and Barratt, 2020). Annual incidence of $\operatorname{IgAN}$ is around 2.5/100 000 people (McGrogan et al., 2011). Imbalance of the disease in the male and female population can be found, and the male-to-female ratio is 2-6 : 1 (Roberts, 2019). Among glomerular diseases, IgAN can lead to end-stage kidney disease (ESRD) (Rodrigues et al., 2017). There is still no effective treatment for this disease, and the main goal of IgAN treatment is blood-pressure and proteinuria control, along with the maintenance of residual kidney function (Lai et al., 2016).

IgAN progression is uncertain, and there are no clearly defined criteria for disease outcome. IgAN prognosis has been based on clinical and histological parameters until now. 
Clinical parameters that are associated with poor prognosis are hypertension, 24-hour proteinuria, and decreased glomerular filtration rate (GFR) at the time of the biopsy; patient race, gender, and comorbidities can also affect disease outcome (Rodrigues et al., 2017). IgAN is heterogeneous in clinical presentation in different populations, displaying surprising geographic variation. For example, IgAN is the most common cause of kidney failure in Asia but it is very rare among individuals of African ancestry (Kiryluk et al., 2012). Histological parameters that determine IgAN prognosis are included in the Oxford Classification of Immunoglobulin A nephropathy (MEST score): mesangial hypercellularity (M); endocapillary hypercellularity (E); segmental glomerulosclerosis (S); and tubular atrophy/interstitial fibrosis (T). This classification was published in 2009 and is an international system for evaluating pathological features on kidney biopsy. Since it was unknown whether kidneypathology lesions in IgAN are correlated with kidney outcome, VALIGA (a validation study of the Oxford classification for IgA nephropathy) started in 2010. The study identified four variables $(\mathrm{M}, \mathrm{E}, \mathrm{S}$, and $\mathrm{T})$ that are strongly correlated with the clinical outcome, independently of known risk factors (presence of hypertension, reduced GFR, severity of proteinuria, blood pressure) at the time of diagnosis. Furthermore, the tubular atrophy/interstitial fibrosis (T) score is the strongest predictor of kidney survival. In 2017, the Oxford classification was updated with the addition of crescent scores $(C)$ that showed association with the rate of GFR loss, even in treated patients with immunosuppression (Cheng and Barratt, 2018; Coppo et al., 2020).

The novel international IgAN prediction tool (PT) was published in April 2019 (New International IgAN ...). PT is an innovation in determination of IgAN prognosis because it combines both clinical and histological parameters in one risk-prediction tool that may provide us with accurate information about disease progression. This PT was designed to predict the risk of $50 \%$ decline in GFR or ESRD and can globally be applied at the time of kidney biopsy to multiple ethnic groups. For risk calculation, the following patient data are required at the time of biopsy: age, race, estimated GFR, blood pressure, proteinuria, use of medications that block the renin-angiotensin system (angiotensin-converting enzyme inhibitors (ACEIs) and angiotensin II receptor blockers (ARBs)), immunosuppression use at or prior to biopsy, and the Oxford MEST-C histology score (Barbour et al., 2019), but without the $\mathrm{C}$ score (crescent), because the PT authors found crescents significantly correlated with race/ethnicity and immunosuppression after the biopsy (Barbour et al., 2019). This study included a large group of 3927 patients from Europe, North America, China, and Japan; there were no other available studies about PT validation in other countries and regions.

Taking into consideration that there is evidence to suggest that true variation in disease frequency may exist between populations of different ethnicity, PT should be evaluated before its use in the further clinical practice of nephrologists. Our study aimed to clarify PT reliability in an adult
Latvian population. PT could help to decide the best treatment plan for each patient and have greater diseaseprognosis reliability in clinical practice.

\section{MATERIALS AND METHODS}

Our research was a retrospective cohort study at Pauls Stradiņš Clinical University Hospital Nephrology Centre (PSCUH). Mandatory data such as age, race, estimated GFR level, systolic (SBP) and diastolic blood pressure (DBP), 24-hour proteinuria, use of ACEI or ARB at the time of biopsy, use of immunosuppression at or prior to biopsy, and MEST scores for PT were collected. GFR was calculated by the chronic-kidney-disease epidemiology-collaboration (CKD-EPI) formula (eGFR using CKD-EPI...; Levey et al., 2009). Adults who were at least 18 years old, with a morphologically confirmed IgAN by the presence of $\operatorname{IgA}$ deposits by immunofluorescence microscopy from 1 January 2013 to 1 November 2019, were included in this study.

We used descriptive statistics to describe our study population. Kidney survival was analysed with the Kaplan-Meier method, and statistical comparison was analysed by a logrank test. Kidney survival was defined as having a GFR 15 $\mathrm{ml} / \mathrm{min} / 1.73 \mathrm{~m}^{2}$ within five years after the biopsy.

\section{Definitions:}

1. Predicted risk - risk of $50 \%$ decline in GFR or ESRD calculated by the novel international IgAN prediction tool;

2. Observed risk - risk of $50 \%$ decline in GFR or ESRD calculated by the Cox regression model considering the same parameters as in the PT.

To compare our data to the novel international IgAN prediction tool, the following tests were performed:

1. Observed risk calculation by the Cox regression model.

2. Intraclass correlation coefficient to describe the strength of the resemblance of PT and Cox regression.

3. We calculated differences between predicted and observed risks, and the results were interpreted as follows:

- if the difference was below zero (negative), we concluded that PT assigned lower risk than our observed risk; and

- if the difference was above zero (positive), we concluded that PT assigned higher risk than our observed risk.

All $p$-values less than 0.05 were considered statistically significant, except Hazard ratio $p$-values that were considered statistically significant with smaller values (less than 0.2 ). Rates of episodes per patient year were calculated in two patient groups, with patients included in (1) Kaplan-Meier analysis, and the Cox regression model with (2) five-year analysis. 
Table 1. Oxford classification of immunoglobulin A nephropathy (IgAN) (Cheng and Barratt, 2018)

\begin{tabular}{|c|c|c|}
\hline Histologic variable & Definition & Score \\
\hline $\begin{array}{l}\text { Mesangial hypercellularity } \\
\text { (M) }\end{array}$ & $\begin{array}{l}\text { Mesangial hypercellularity } \\
\text { score defined by proportion } \\
\text { of glomeruli with mesangial } \\
\text { hypercellularity. }\end{array}$ & $\begin{array}{l}\mathrm{M} 0 \leq 50 \% \\
\mathrm{M} 1>50 \%\end{array}$ \\
\hline $\begin{array}{l}\text { Endocapillary } \\
\text { hypercellularity (E) }\end{array}$ & $\begin{array}{l}\text { Hypercellularity because of } \\
\text { increased number of cells } \\
\text { within glomerular capillary } \\
\text { lumina, causing narrowing } \\
\text { of lumina. }\end{array}$ & $\begin{array}{l}\text { E0-absent } \\
\text { E1-present }\end{array}$ \\
\hline $\begin{array}{l}\text { Segmental } \\
\text { glomerulosclerosis (S) }\end{array}$ & $\begin{array}{l}\text { Any amount of tuft in- } \\
\text { volved in sclerosis, but not } \\
\text { involving the whole tuft or } \\
\text { the presence of an adhesion. }\end{array}$ & $\begin{array}{l}\text { S0_-absent } \\
\text { S1-present }\end{array}$ \\
\hline $\begin{array}{l}\text { Tubular atrophy/interstitial } \\
\text { fibrosis }(\mathrm{T})\end{array}$ & $\begin{array}{l}\text { Percentage of cortical area } \\
\text { involved by tubular atrophy } \\
\text { or interstitial fibrosis, } \\
\text { whichever is greater. }\end{array}$ & $\begin{array}{l}\text { T0 } 0 \%-25 \% \\
\text { T1 } 26 \%-50 \% \\
\text { T2 }>50 \%\end{array}$ \\
\hline
\end{tabular}

In the first group, episodes were defined as GFR less than $15 \mathrm{ml} / \mathrm{min} / 1.73 \mathrm{~m}^{2}$; in the second group, episodes were defined according to PT definition, with 50\% decline in GFR or ESRD five years after the biopsy.

Histologic changes in both PT and our centre study were scored according to Oxford IgAN classification criteria (see Table 1) (Cheng and Barratt, 2018).

Data were analysed by R v.4.0.1 (R Core Team (2020): R: A language and environment for statistical computing; $\mathrm{R}$ Foundation for Statistical Computing, Vienna, Austria and IBM SPSS Statistics 22.0.

The present study was approved by the PSCUH Ethics Committee (approval no. 090919-15L; 9 September 2019).

\section{RESULTS}

Our study included 105 patients, all of them Caucasian; 90.5\% ( $\mathrm{n}=95)$ of them were included in Kaplan-Meier analysis, and $9.5 \%(\mathrm{n}=10)$ were excluded due to ESRD at the time of biopsy. Furthermore, 68.8\% $(n=68)$ of all patients were eligible for PT analysis, and $35.2 \%(n=37)$ of the patients were excluded from risk calculation by PT due to secondary IgAN associated with liver disease or IgA vasculitis according to the handout for nephrologists about PT application in clinical practice (The International IgA...); patients with missing data were also excluded. The selected group was analysed by the Cox regression model and PT five years after the biopsy (see Fig. 1).

Demographic and clinical characteristics of included patients are presented in Table 2. Kaplan-Meier analysis of kidney survival included 95 patients, 53 of them men; mean age was $38.6 \pm 11.2$ years (from 18 to 72 years), and median GFR level was $56 \mathrm{ml} / \mathrm{min} / 1.73 \mathrm{~m}^{2}$ (from 16 to 130 $\mathrm{ml} / \mathrm{min} / 1.73 \mathrm{~m}^{2}$ ). Nephritic syndrome was a common IgAN manifestation. Hypertension was present in $56.4 \%$ of patients (SBP $\geq 140 \mathrm{mmHg}$ or/and DBP $\geq 90 \mathrm{mmHg}$ ), and

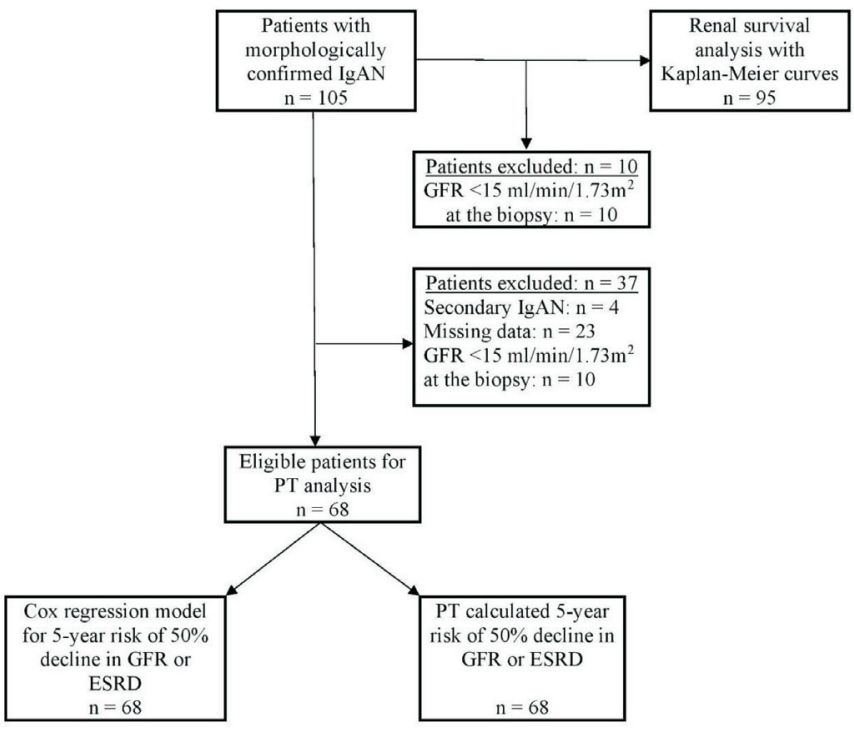

Fig. 1. Overview of the patient-selection process.

$39.62 \%$ of them were using ACEIs/ARBs at the time of biopsy. Histologically findings were as follows: $12.6 \%(\mathrm{n}=$ 12) of patients had M0; E0, $96.8 \%$ of patients ( $n=92)$; S0, $27.4 \%(\mathrm{n}=26)$; and T0 and T1, 82.1\% $(\mathrm{n}=78)$, and $11.6 \%$ $(\mathrm{n}=11)$ of patients, respectively.

In this patient-population event (GFR $<15 \mathrm{ml} / \mathrm{min} / 1.73$ $\mathrm{m}^{2}$ ), the rate was 0.11 episodes per patient year. The median duration of the follow-up was 18.00 months (from 0 to 60 months). In this study overall median kidney survival during the follow-up period (60 months) was not reached, and achieved Q3 was 24 months. Gender, MEST T score, and diastolic blood pressure were significant risk factors for decreased kidney survival. The effect of systolic blood pressure was at the border of statistical significance $(p=0.059)$.

Women had longer median kidney-survival time (more than 60 months) than for men (58 months). A log-rank test was conducted to determine if there were differences in survival distribution for gender; $\chi^{2}(1)=4.03, p=0.045$ (see Fig. 2).

Analysis of kidney survival according to the MEST score showed that patients with MEST T0 had longer median kidney-survival time than the follow-up period (60 months). It was longer than that in patients with $\mathrm{T} 1$ and $\mathrm{T} 2$, which was 40 and 18 months, respectively. There was a statistically significant difference in kidney-survival distribution between T0 and T1 scores $\left(\chi^{2}(2)=9.09, p=0.01\right.$; see Fig. 3$)$. As shown in Figure 3, T1 exhibited a tendency towards better overall survival than $\mathrm{T} 2\left(\chi^{2}\right.$ for trends $=8.80, p=$ 0.003).

Participants with diastolic blood pressure (DBP) of less than 80 to $99 \mathrm{mmHg}$ had longer median kidney survival than the follow-up period (60 months), which was longer than in patients with DBP from 100 to 109 and more than $110 \mathrm{mmHg}$, which was 40 months and 24 months. There was a statistically significant difference in survival distribution between DBP categories $\left(\chi^{2}(4)=11.46, p=0.022\right.$; see Fig. 4). Figure 4 shows the relationship between higher blood pressure and worse kidney survival $\left(\chi^{2}\right.$ for trend $\left.=9.21, p=0.002\right)$. 
Table 2. Demographic and clinical characteristics of patients included in Kaplan-Meier analysis

\begin{tabular}{|c|c|}
\hline $\begin{array}{l}\text { Gender: } \\
\text { Male }\end{array}$ & $\begin{array}{l}\mathrm{n}(\%) \\
53(55.8)\end{array}$ \\
\hline $\begin{array}{l}\text { Age (years): } \\
\text { Mean } \pm \mathrm{SD} \\
\text { Median [Q1-Q3] } \\
\text { Range }\end{array}$ & $\begin{array}{l}38.6 \pm 11.2 \\
37.0[31.0,45.0] \\
18-72\end{array}$ \\
\hline $\begin{array}{l}\text { Age group (years): } \\
\begin{array}{l}18-29 \\
30-39 \\
40-49 \\
50-59 \\
60-69 \\
>70\end{array}\end{array}$ & $\begin{array}{l}19(20.0) \\
38(40.0) \\
21(22.1) \\
12(12.6) \\
4(4.2) \\
1(1.1)\end{array}$ \\
\hline $\begin{array}{l}\text { SBP }(\mathrm{mmHg}) \\
\text { Mean } \pm \text { SD } \\
\text { Median [Q1-Q3] } \\
\text { Range }\end{array}$ & $\begin{array}{l}136 \pm 20.0 \\
135[120,150] \\
100-190\end{array}$ \\
\hline $\begin{array}{l}\mathrm{DBP}(\mathrm{mmHg}): \\
\text { Mean } \pm \text { SD } \\
\text { Median [Q1-Q3] } \\
\text { Range }\end{array}$ & $\begin{array}{l}84.7(13.7) \\
80[71.8,93.0] \\
60-120\end{array}$ \\
\hline $\begin{array}{l}\text { GFR at biopsy }\left(\mathrm{ml} / \mathrm{min} / 1.73 \mathrm{~m}^{2}\right) \\
\text { Mean } \pm \mathrm{SD} \\
\text { Median }[\mathrm{Q} 1-\mathrm{Q} 3] \\
\text { Range }\end{array}$ & $\begin{array}{l}65.7 \pm 36.0 \\
56[33.0,98.0] \\
16-130\end{array}$ \\
\hline $\begin{array}{l}\text { CKD stages }\left(\mathrm{ml} / \mathrm{min} / 1.73 \mathrm{~m}^{2}\right) \\
\text { I: }>90 \\
\text { II: } 60-89 \\
\text { III: } 30-59 \\
\text { IV: } 15-29 \\
\text { V: }<15\end{array}$ & $\begin{array}{l}32(33.7) \\
16(16.8 \\
25(26.3) \\
22(23.2) \\
0(0)\end{array}$ \\
\hline $\begin{array}{l}\text { Daily proteinuria }(\mathrm{g} / 24 \mathrm{~h}) \text { : } \\
\text { Mean } \pm \mathrm{SD} \\
\text { Median }[\mathrm{Q} 1-\mathrm{Q} 3] \\
\text { Range }\end{array}$ & $\begin{array}{l}1.78 \pm 1.87 \\
1.17[0.5,2.33] \\
0.10-11.50\end{array}$ \\
\hline $\begin{array}{c}\operatorname{MEST}(\mathrm{M}) \text { : } \\
\text { M0 } \\
\text { M1 }\end{array}$ & $\begin{array}{l}12(12.6) \\
83(87.4)\end{array}$ \\
\hline $\begin{array}{l}\text { MEST }(\mathrm{E}) \text { : } \\
\quad \text { E0 } \\
\text { E1 }\end{array}$ & $\begin{array}{l}92(96.8) \\
3(3.2)\end{array}$ \\
\hline $\begin{array}{l}\operatorname{MEST}(\mathrm{S}): \\
\quad \text { S0 } \\
\text { S1 }\end{array}$ & $\begin{array}{l}26(27.4) \\
69(72.6)\end{array}$ \\
\hline $\begin{array}{c}\text { MEST }(\mathrm{T}): \\
\text { T0 } \\
\text { T1 } \\
\text { T2 }\end{array}$ & $\begin{array}{l}78(82.1) \\
11(11.6) \\
6(6.3)\end{array}$ \\
\hline $\begin{array}{l}\text { Use of ACEIs or ARBs at time of biopsy: } \\
\text { Yes } \\
\text { No }\end{array}$ & $\begin{array}{l}37(38.9) \\
58(61.1)\end{array}$ \\
\hline $\begin{array}{l}\text { Immunosuppression at or prior to biopsy: } \\
\text { Yes } \\
\text { No }\end{array}$ & $\begin{array}{l}9(9.5) \\
86(90.5)\end{array}$ \\
\hline $\begin{array}{l}\text { Glomerular manifestations: } \\
\text { Nephritic syndrome } \\
\text { Nephrotic syndrome } \\
\text { Nephrotic and nephritic syndrome } \\
\text { Isolated haematuria } \\
\text { Isolated proteinuria }\end{array}$ & $\begin{array}{l}69(73.4) \\
1(1.1) \\
13(13.8) \\
7(7.4) \\
4(4.3)\end{array}$ \\
\hline
\end{tabular}

In this study, survival distribution for age, 24-hour proteinuria, use of ACEIs/ARBs at the time of biopsy, the use of immunosuppression at or prior to biopsy, and MEST M, E,
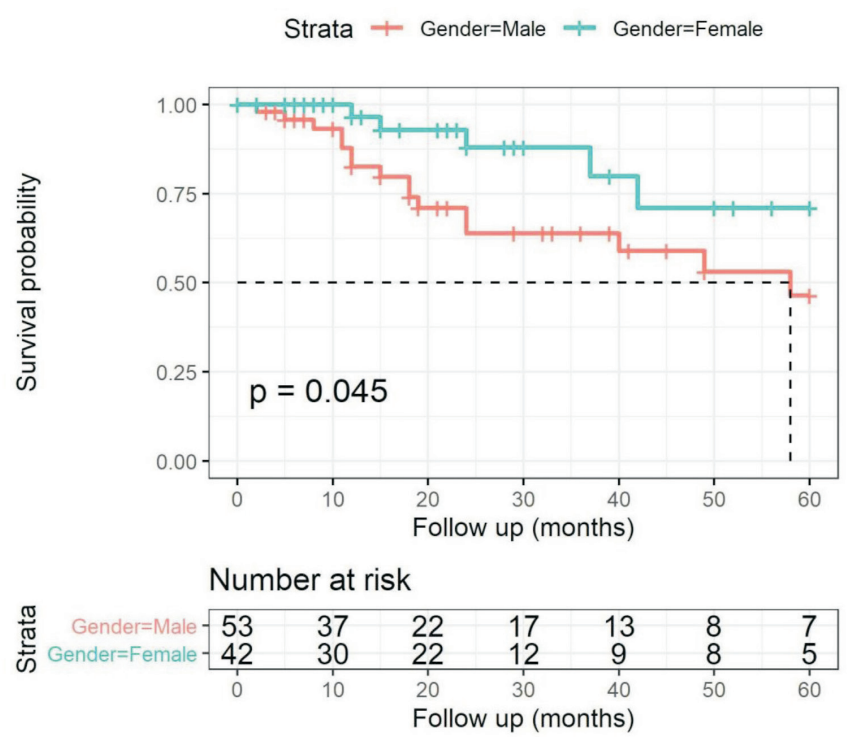

Fig. 2. Cumulative kidney-survival rates categorised by gender.
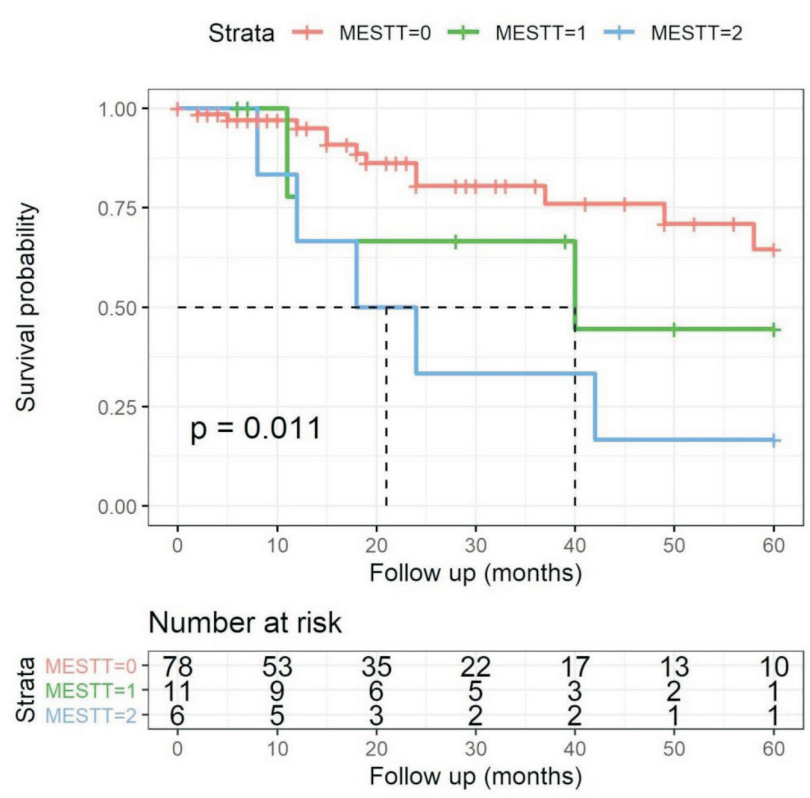

Fig. 3. Cumulative kidney -survival rates categorised by tubular atrophy/interstitial fibrosis (MEST T) score.

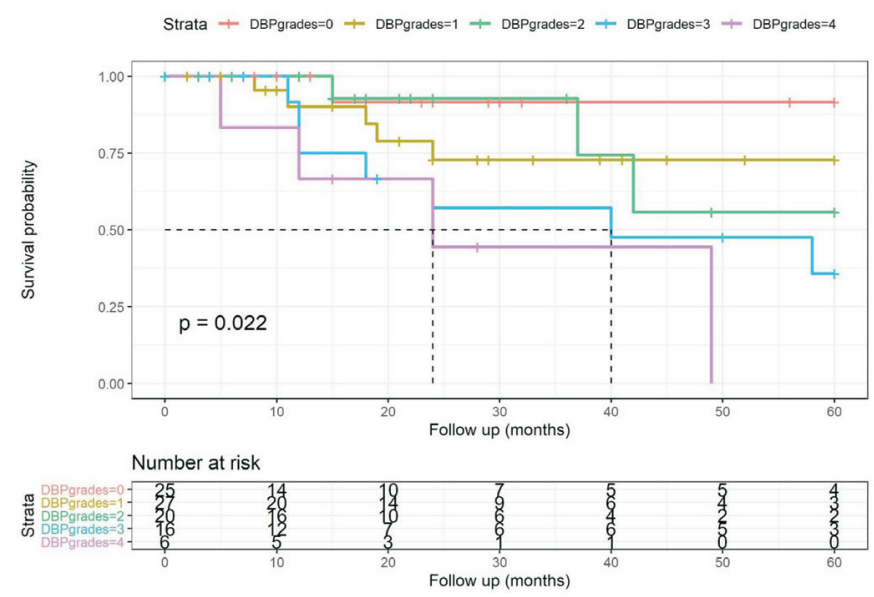

Fig. 4. Cumulative kidney-survival rates categorised by diastolic blood pressure.

DBP: grade $0-<80 \mathrm{mmHg}$; grade $1-80-89 \mathrm{mmHg}$; grade $2-90-99$ $\mathrm{mmHg}$; grade 3 - 100-109 $\mathrm{mmHg}$; grade $4-\geq 110 \mathrm{mmHg}$. 
Table 3. Hazard ratio analysis of various clinical parameters

\begin{tabular}{lc|c}
\hline \multicolumn{1}{c|}{ Factor } & $\begin{array}{c}\text { Hazard ratio } \\
\text { (95\% confidence interval })\end{array}$ & $p$-value \\
\hline Age & $0.95(0.91-0.99)$ & 0.023 \\
Systolic blood pressure & $0.99(0.96-1.03)$ & 0.683 \\
Diastolic blood pressure & $1.06(1.00-1.12)$ & 0.04 \\
MEST E & $4.12(0.83-20.47)$ & 0.084 \\
MEST T & $2.52(1.38-4.62)$ & 0.003
\end{tabular}

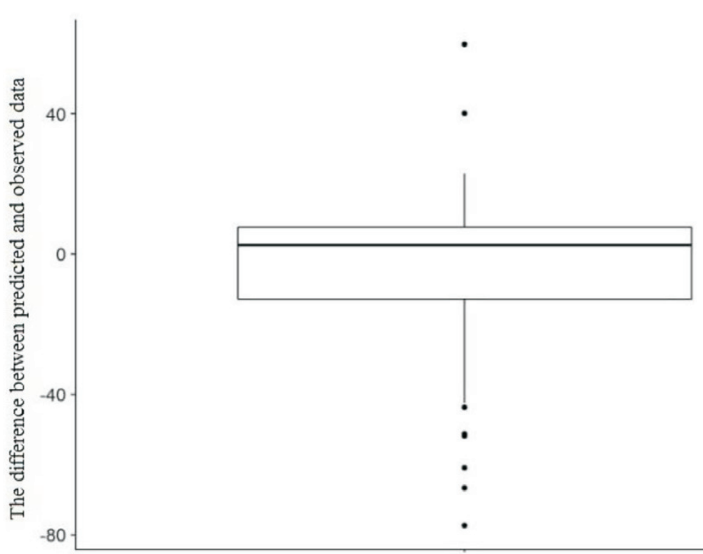

Fig. 5. PT and Cox regression-model difference of estimated risks (five-year analysis).

and S scores were not significantly related with kidney survival.

The study population for Cox Regression analysis Event rate (50\% decline in GFR or ESRD) was 0.15 episodes per patient year for five-year analysis. The median follow-up duration was 21.5 months (from 0 to 60 months) for fiveyear analysis. A total of 68 patients were included for Cox regression analysis; 37 of them were men, and the patient mean age was $39.1 \pm 12.0$ years (range from 18 to 72 years). We excluded 37 patients from the study due to missing data, secondary $\operatorname{IgAN}$ (IgA vasculitis, liver disease), and GFR $\mathrm{ml} / \mathrm{min} / 1.73 \mathrm{~m}^{2}$ at the time of biopsy. Glomerular manifestations were analysed in $98.5 \%(n=67)$ of patients due to missing data. Table 2 lists the demographic and clinical characteristics of patients.

Hazard ratio analysis showed that diastolic blood pressure, MEST E and MEST T were associated with the risk of 50\% decline in GFR or ESRD, respectively (see Table 3). A $6 \%$ increase in risk was observed with every next DBP grade. There was a 4-fold increase in the risk for each MEST E score and more than two times for each MEST T score. Age was a protective factor, and every year the risk decreased by $5 \%$.

The intraclass correlation coefficient showed that there was a moderate degree of reliability between predicted and observed five-year risk. The average-measure intraclass correlation coefficient was 0.70 with a $95 \%$ confidence interval from 0.52 to $0.82(\mathrm{~F}(67,67)=3.38, p=0.001)$. The differences between predicted and observed data were mostly insignificant from 0 to $10 \%(n=33)$; the median difference was $2.54 \%$. This proves a good reliability of PT. It assigned lower risk than our estimated risk to 23 patients, but the risk was similar or slightly higher in 45 patients However, the predicted maximal negative and maximal positive differences were $77.35 \%$ and $59.84 \%$, respectively. On closer analysis of these two study participants, no exceptional features in their disease course or histology results were found (see Fig. 5).

\section{DISCUSSION}

This study consisted of two parts: the first was focused on actual kidney-survival analysis, and the second draws attention to IgAN PT validation in our study population. To our knowledge, this is the first study that tested PT, and compared predicted and observed risks of kidney-disease progression, after the PT became available online.

Routine detection of immunoglobulins including IgA in kidney biopsies became available in Latvia from 2013, and all patients from that moment were included in this study. Several studies indicated that hypertension prevalence in IgAN patients may vary between $19 \%$ and $53 \%$ at the time of kidney biopsy (Nagy et al., 2005). In our study group, $57.3 \%(\mathrm{n}=59)$ of included patients had hypertension defined as $\mathrm{SBP} \geq 140 \mathrm{mmHg}$ and/or DBP $\geq 90 \mathrm{mmHg}$, and only 22 were using ACEIs/ARBs at the time of biopsy. This can be explained by the late referral to a nephrologist in the absence of other clinical symptoms. In this study, we found that the blood pressure affects kidney survival; patients with lower blood pressure had longer kidney survival. Rauen et al. (2018) found that kidney function at the time of histological glomerulonephritis diagnosis is associated with clinical outcome and concluded that better prognosis may be related to the early initiation of a specific drug treatment (Rauen et al., 2018). However, there is currently no specific treatment for IgAN, and the STOP-IgAN trial proved that even immunosuppressive therapy cannot prevent GFR loss (Rauen et al., 2018). Therefore, further research on IgAN pathogenesis and new therapeutic targets is an ongoing global process.

The five-year kidney survival time was $57 \%$ in our study group, while the Japanese study of 30-year analysis of kidney survival $(\mathrm{n}=1012)$ showed that five-year kidney survival was more than $90 \%$ (Moriyama et al., 2014). Statistically significant kidney-survival-affecting factors were gender, MEST T score, and diastolic blood pressure. In our study, we observed that patients with T0 had median kidney-survival time that was longer than five years, and patients with $\mathrm{T} 1$ had a median kidney-survival time of 40 months, but patients with T2 had a shorter kidney-survival time, 18 months. A French study that included 61 participants established that MEST T and S scores affected kidney survival, but MEST $\mathrm{M}$ and $\mathrm{E}$ scores did not affect kidney outcome; patients with T0 and T1 had kidney survival greater than five years, in comparison with T2, where kidney survival was only ten months. The authors of this study concluded that MEST T scores were associated with poor kidney outcome (Hennino et al., 2016). The VALIGA study 
and secondary analysis of the STOP-IgAN study also showed that $\mathrm{T}$ scores were related with GFR loss and worse kidney outcomes (Schimpf et al., 2018; Coppo et al., 2020).

Another retrospective study of kidney-survival analysis was published in 2003. This study included patients from four different countries in three continents and aimed to analyse long-term IgAN outcomes. This study observed that 10 -year kidney survival was $95.7 \%$ in Helsinki (Finland), $87.0 \%$ in Sydney (Australia), 63.9\% in Glasgow (United Kingdom), and $61.6 \%$ in Toronto (Canada). In addition, kidneysurvival-curve analysis showed five-year kidney survival in 98\% (Helsinki), 95\% (Sydney), and 79\% (Glasgow and Toronto) of cases (Colin et al., 2003). If we compare our study to the Japanese and tricontinental studies, we can conclude that, in Latvia, disease courses are more aggressive, and patients reach ESRD earlier. Indications of kidney biopsy in each country certainly play a role. In Japan, a kidney biopsy is performed in all patients with suspected glomerulonephritis; in Latvia, diagnosis verification is usually done in patients with other kidney manifestations like proteinuria, hypertension, or GFR decline. Patients with isolated haematuria are frequently not referred for biopsy.

IgAN progression may vary by geographic region. There could be genetic influence on the course of the disease, because IgAN occurs in families and in HLA-identical siblings. There is increased frequency of certain HLA and complement genotypes in some populations, as well as genetic predisposition of aberrant glycosylation, which is one of the main components of IgAN pathogenesis (Rodrigues et al., 2017; Kumar et al., 2018; Schena and Nistor, 2018; Roberts, 2019). Since the Middle Ages, the territory of Latvia has been a frequent focal point for conquests from Germany, Poland, Sweden, and Russia due to its strategic location. The Baltic Sea was a geographical barrier to human migration when changes in the genetic constitution due to migration were most profound. Modern molecular genetic investigations of the Latvian population began only 20 years ago. Review authors about Latvian population genetics observed that the mitochondrial DNA of Latvians is genetically similar in general with that of a majority of other Europeans, but the Y-chromosomal lineage composition suggests that Latvians are more similar to Northern and Eastern European populations like Lithuanians, Estonians, and Eastern Slavic populations due to ethnological proximity to them. Ancient DNA analysis did not observe any genomic evidence of gene flow from Central European farmers, or any typically mitochondrial or Y-chromosome haplogroups for them in hunter gatherers from the territory of today's Latvia and Lithuania (Krūmina et al., 2018). Genetic analysis of IgAN progression in the Latvian population could be an important topic of further research in the future.

Since there was no validated tool to predict IgAN progression, the PT authors derived and validated a prediction tool for disease-progression determination. The study population of "evaluating a new international risk-prediction tool in IgA nephropathy" was patients from multiethnical cohorts of adults with biopsy-proven IgAN, and it included patients from Oxford, North American, and VALIGA studies. In VALIGA, patients from 53 centres in 13 countries were enrolled, and it included only one centre from the Baltic States (Estonia, Tartu), but many centres from Italy; this could indicate that the study population was nonhomogeneous (Barbour et al., 2019; Coppo et al., 2020). Considering that the course of IgAN may vary in different geographical areas, and the Latvian population may differ from the general population of Europe, it is important to clarify the disease course in the Latvian population. Before the PT was published, the treatment decision was based on patient clinicopathologic features; however, as mentioned in the PT authors' publication, clinical trials suggested that $33 \%$ of patients who did not meet clinical-treatment criteria but had high MEST scores did not receive treatment and experienced a decrease of kidney function, and more than $75 \%$ of patients with low-risk nonprogressive disease were unnecessarily treated (Barbour et al., 2019). There were some patients in our study already with ESRD at the time of biopsy, so we agree with the authors' opinion that the PT can potentially improve clinical-treatment decisions, and it is possible to identify high-risk patients before IgAN progresses to ESRD.

Before we accept PT for the clinical practice of nephrologists in Latvia, we needed to verify PT reliability in our study population. In this study, we observed that the predicted and observed risk of 50\% decline in GFR or ESRD were similar. In addition, we found that the predicted and observed results moderately resembled each other for fiveyear analysis. The results were similar, so PT is reliable for use in Latvian population. There has been only one study with a similar design about PT validation available until now, besides that from the PT authors. Zhang et al. (2020) externally validated the PT using a large cohort of 1373 patients with biopsy-proven primary IgAN from central China. The authors validated PT to predict five-year risk of kidney outcomes; however, the median follow-up of their cohort was 29 months. They concluded that PT can be applied in clinical practise for individual patients at an early disease stage and further multicentre studies are required to change clinical decisions (Zhang et al., 2020).

In both humans and laboratory animals, the specific causes underlying the sex differences in kidney disease progression are unclear but have been speculated to involve factors such as innate sex-related variability in kidney size, weight, and nephron number, gender differences in systemic and glomerular haemodynamics, differences in diet, and the direct effects of estrogens and androgens on kidney tissue (Silbiger, 2011). Gender affected kidney survival, with women having longer kidney survival than men, and there were differences between predicted and observed data; for females, predicted and observed risks were more similar compared with those for males. Meta-analysis of randomised controlled trials about ACEI/ARB agent effects on IgAN showed that, in comparison with the control groups, ACEIs/ARBs agents had statistically significant effects on protecting kidney 
function (Cheng et al., 2009). MEST scores are important factors that influence $\operatorname{IgAN}$ prognosis. More precisely, it was found that mesangial hypercellularity (M) and tubular atrophy/ interstitial fibrosis (T) were associated with poor kidney outcome (Barbour et al., 2016; Chen et al., 2018). We found that tubular atrophy/interstitial fibrosis $(\mathrm{T})$ had statistically significant impact on kidney survival, and mesangial hypercellularity (M) did not have a statistically significant effect on kidney survival, but it affected differences between PT and estimated risk.

Our study had some limitations. The main limitation was the relatively small study cohort, and insufficient data about kidney function and disease course after five years (for example, for patients who had a kidney biopsy in 2018). This was a retrospective design study. Some of the patients were excluded from the study due to missing information in medical records or secondary IgAN. Patients receiving immunosuppressive therapy and its effects were not separately analysed. This study needs to be performed in a larger cohort with a longer follow-up period (ten years, for example) for more accurate data analysis. This would allow for more precise data comparison with those of other studies. This is possible after the creation of a single database for the Baltic region.

\section{CONCLUSIONS}

Episodes per patient years were less than 0.20 in both Kaplan-Meier analysis, and the five-year Cox regression-model group. More than a half of the study population had longer kidney survival than five years. Kidney-survival-affecting factors were gender, tubular atrophy/interstitial fibrosis (MEST T), and diastolic blood pressure. Notwithstanding ethnic and demographic differences between our cohort and the population in the PT study, predicted and observed risk of $50 \%$ decline in GFR or ESRD were similar. Therefore, this tool can be applied to IgAN patients in the Latvian population.

\section{ACKNOWLEDGEMENTS}

This article publication is funded by Rīga Stradiňš University, Fundamental and Applied Research Project lzp-2019/1-0139.

\section{REFERENCES}

Barbour, S. J., Coppo, R., Zhang, H., Liu, Z. H., Suzuki, Y., Matsuzaki, K., Katafuchi, R., Er, L., Espino-Hernandez, G., Kim, S. J., Reich, H. N., Feehally, J., Cattran, D. C. (2019). International IgA nephropathy network. Evaluating a new International Risk-Prediction Tool in IgA Nephropathy. JAMA Intern Med., 179 (7), 942-952. Erratum in: JAMA Intern Med., 2019, 179 (7), 1007.

Barbour, S. J., Espino-Hernandez, G., Reich, H. N., Coppo, R., Roberts, I. S., Feehally, J., Herzenberg, A. M., Cattran, D. C. (2016). The MEST score provides earlier risk prediction in $\lg \mathrm{A}$ nephropathy. Kidney Int., 89 (1), 167-175
Chang, A., Laszik, Z. (2018). Kidney and its collecting system. In: Vinay, K., Abbas, A. K., Aster, J. C. (eds.). Robbins Basic Pathology. Elsevier, Philadelphia, Chapter 14, pp. 549-581.

Chen, D., Liu, J., Duan, S., Chen, P., Tang, L., Zhang, L., Feng, Z., Cai, G., Wu, J., Chen, X. (2018). Clinicopathological features to predict Pprogression of IgA nephropathy with mild proteinuria. Kidney Blood Press Res., 43 (2), 318-328.

Cheng, J., Zhang, W., Zhang, X. H., He, Q., Tao, X. J., Chen, J. H. (2009). ACEI/ARB therapy for IgA nephropathy: A meta-analysis of randomised controlled trials. Int. J. Clin. Pract., 63 (6), 880-888.

Cheng, Y. S., Barratt, J. (2018). Immunoglobulin A nephropathy and related disorders. In: Gilbert, S., Weiner, D. E. National Kidney Foundation Primer on Kidney Diseases. Elsevier, Edinburgh. 680 pp.

Cheung, C. K., Barratt, J. (2020). IgA nephropathy: Pathogenesis. https://www.uptodate.com/contents/iga-nephropathy-pathogenesis (accessed 15.09.2021).

Coppo, R., D'Arrigo, G., Tripepi, G., Russo, M. L., Roberts, I. S. D., Bellur, S., Cattran, D., Cook, T. H., Feehally, J., Tesar, V., et al. (2020). Is there long-term value of pathology scoring in immunoglobulin A nephropathy? A validation study of the Oxford Classification for IgA Nephropathy (VALIGA) update. Nephrol. Dial. Transplant., 35 (6), 1002-1009.

Duan, Z. Y., Cai, G. Y., Chen, Y. Z., Liang, S., Liu, S. W., Wu, J., Qiu, Q., Lin, S. P., Zhang, X. G., Chen, X. M. (2013). Aging promotes progression of IgA nephropathy: A systematic review and meta-analysis. Amer. J. Nephrol., 38 (3), 241-252.

Geddes, C. C., Rauta, V., Gronhagen-Riska, C., Bartosik, L. P., Jardine, A. G., Ibels, L. S., Pei, Y., Cattran, D. C. (2003). A tricontinental view of IgA nephropathy. Nephrol. Dial. Transplant., 18 (8), 1541-1548.

eGFR using CKD-EPI.

https://qxmd.com/calculate/calculator_251/egfr-using-ckd-epi (accessed 15.09.2021)

Hennino, M., Buob, D., van der, Hauwaert, C., Gnemmi, V., Jomaa, Z., Pottier, N., Savary, G., Drumez, E., Noėl, C., Cauffiez, C., Glowacki, F. (2016). miR-21-5p renal expression is associated with fibrosis and renal survival in patients with IgA nephropathy. Sci. Rep., 6, 27209 (2016).

Kiryluk, K., Li, Y., Sanna-Cherchi, S., Rohanizadegan, M., Suzuki, H., Eitner, F., Snyder, H. J., Choi, M., Hou, P., Scolari, F., et al. (2012). Geographic differences in genetic susceptibility to IgA nephropathy: GWAS replication study and geospatial risk analysis. PLoS Gen., 8 (6), e1002765.

Krūmina, A., Pliss, L., Zarina, G., Puzuka, A., Zarina, A., Lāce, B., Elferts, D., Khrunin, A., Limborska, S., Kloviņ̌̌, J., Gailīte Piekuse, L. (2018). Population genetics of Latvians in the context of admixture between North-Eastern European ethnic groups. Proc. Latvian Acad. Sci., Section B, 72 (3), 131-151.

Lai, K., Tang, S., Schena, F., Novak, J., Tomino, Y., Fogo, A. B., Glassock, R. J. (2016). IgA nephropathy. Nat. Rev. Dis. Primers, 2, 16001.

McGrogan, A., Franssen, C. F. M., Vries, C. S. (2011). The incidence of primary glomerulonephritis worldwide: A systematic review of the literature. Nephrol. Dial. Transplant., 26 (2), 414-430.

Moriyama, T., Tanaka, K., Iwasaki, C., Oshima, Y., Ochi, A., Kataoka, H., Itabashi, M., Takei, T., Uchida, K., Nitta, K. (2014). Prognosis in IgA nephropathy: 30 -year analysis of 1,012 patients at a single center in Japan. PLoS One, 9 (3), e91756.

Nagy, J., Kovács, T., Wittmann, I. (2005). Renal protection in IgA nephropathy requires strict blood pressure control. Nephrol. Dial. Transplant., 20 (8), 1533-1539.

New International IgAN Prediction Tool.

https://qxmd.com/calculate/calculator_499/international-igan-prediction-tool (accessed 13.10.2021).

Rauen, T., Fitzner, C., Eitner, F., Sommerer, C., Zeier, M., Otte, B., Panzer, U., Peters, H., Benck, U., Mertens, P. R. et al. (2018). Effects of two 
immunosuppressive treatment protocols for IgA nephropathy. J. Amer. Soc. Nephrol.,, 29 (1) 317-325.

Roberts, I. S.D. (2019). Kidney diseases. In: Cross, S. S. (Ed.). Underwood's Pathology: A Clinical Approach. Elsevier, Edinburgh, pp. 494-522.

Rodrigues, J. C., Haas, M., Reich, H. N. (2017). IgA Nephropathy. Clin. J. Amer. Soc. Nephrol., 12 (4), 677-686.

Schena, F. P., Nistor, I. (2018). Epidemiology of IgA nephropathy: A global perspective. Seminars in Nephrology, 38 (5), 435-442.

Schimpf, J. I., Klein, T., Fitzner, C., Eitner, F., Porubsky, S., Hilgers, R. D., Floege, J., Groene, H. J., Rauen, T. (2018). Renal outcomes of STOP-IgAN trial patients in relation to baseline histology (MEST-C scores). BMC Nephrol., 19 (1), 328.

Silbiger, S. R. (2011). Raging hormones: Gender and renal disease. Kidney Int., 79 (4), 382-384.

Received 29 December 2020

Accepted in the final form 27 March 2021
Levey, A. S., Stevens, L. A., Schmid, C. H., Zhang, Y., Castro, III, A. F., Feldman, H. I., Kusek, J. W., Eggers, P., van Lente, F., Greene, T., Coresh, J. (2009). A new equation to estimate glomerular filtration rate. Ann. Intern. Med., 150, 604-612.

The International IgA NEPHROPATHY (IgAN). Prediction Tool Information for nephrologists and other healthcare professionals. https://ukkidney.org/sites/renal.org/files/2-IgAN-Risk-Prediction-Tool-info-for-Health-Professionals.pdf (accessed 15.09.2021).

Zhang, J., Huang, B., Liu, Z., Wang, X., Xie, M., Guo, R., Wang, Y., Yu, D., Wang, P., Zhu, Y., Ren, J. (2020). External validation of the International IgA Nephropathy Prediction Tool. Clin. J. Amer. Soc. Nephrol., 15 (8) 1112-1120.

\section{NIERU DZĪVILDZE UN JAUNĀ STARPTAUTISKĀ IMŪNGLOBULĪNA A NEFROPĀTIJAS PROGNOZES KALKULATORA VALIDĀCIJA LATVIJAS POPULĀCIJĀ: PRELIMINĀRIE DATI}

Imūnglobulīna A nefropātija (IgAN) ir biežākais glomerulonefrīta veids visā pasaulē, taču slimības ǵeogrāfiskā izplatība un klīniskās pazīmes ievērojami atškiras. Retrospektīva kohortas pētījuma mērḳis bija noteikt nieru piecu gadu dzīvildzi, izmantojot Kaplana-Meiera metodi) un validēt starptautisko IgAN prognozes kalkulatoru (PK), izmantojot Koksa regresijas analīzi Latvijas populācijā. Pētījums tika veikts Paula Stradiṇa Klīniskās universitātes slimnīcas Nefrolog̣ijas centrā un tajā tika iekḷauti vismaz 18 gadus veci pacienti ar histoloğiski apstiprinātu IgAN diagnozi. Kaplana-Meiera analīzē tika iekḷauti 95 pacienti, un nieru piecu gadu dzīvildzes Q3 bija 24 mēneši. Nieru dzìvildzes mediāna sievietēm bija ilgāka (> 60 mēneši) nekā vīriešiem (58 mēneši), $p=0,045$. Pacientiem ar MEST T0 nieru dzīvildzes mediāna bija > 60 mēneši, T1 un T2 tā bija, attiecīgi, 40 un 18 mēneši. Pacientiem ar diastolisko asinsspiedienu (DAS) > 99 mmHg mediānā nieru dzīvildze bija > 60 mēneši, savukārt, pacientiem ar DAS 100-109 un $\geq 110$ mmHg tā bija attiecīgi 40 un 24 mēneši. Koksa regresijas analīzē tika iekḷauti 68 pacienti, un tika novērota mērena ticamība starp aprēkinātu risku ar PK un Koksa regresiju. Rezultāti liecina, ka starptautisko IgAN prognozes kalkulatoru varētu izmantot nefrologu klīniskajā praksē Latvijā. 